\title{
Transformasi Pendidikan Maros
}

\author{
Ismail Suardi Wekke \\ Dewan Pendidikan Kabupaten Maros \\ Email: iswekke@gmail.com
}

Ketika duduk di bangku Sekolah Dasar, masih kelas-kelas awal saya kemudian menemani nenek untuk menemui para petinggi kecamatan. Ketika itu, saya tidak faham apa yang terjadi.

Puluhan tahun setelahnya, kemudian memahami bahwa ada bagian dari tanah yang sekarang ini berdiri SMA Negeri Camba dimana merupakan tanah milik nenek bersaudara yang kemudian dibeli oleh pemerintah untuk keperluan pembangunan SMA.

Ketikan ini, bukan penjualan tanah itu. Tetapi setakat memori bahwa SMA yang ada di Lappa-pai sekarang ini tidaklah berdiri sejak dulu. Kalaulah saya di SD kelas satu tahun 1983, maka setelah itulah SMA berdiri.

Walaupun tidak ada SMA sebelum itu, tetapi masyarakat Camba tetaplah berniat mengirim anakanaknya untuk sekolah ke tingkat lanjut. Walau harus "menumpang" di rumah keluarga. Ada pula dari masyarakat yang jikalau tidak mendapatkan keluarga yang bisa dititipkan sebagai tempat untuk menimba ilmu pengetahuan, mereka kemudian berada di panti asuhan sebagai tempat mondok.

Bahkan sepupu-sepupu saya kemudian menyelesaikan pendidikan di SMK dimana belum tersedia di Camba, mereka menikmati tinggal di panti asuhan demi penyelesaian studi. Walaupun ibubapaknya lengkap, dengan bukan status yatim tetapi memilih tinggal di panti asuhan.

Sampai tahun 1995, masyarakat Ladangnge untuk menempuh pendidikan lanjutan pertama masih perlu menempuh perjalanan sampai ke Camba. Sampai kemudian berdirinya SMP di Ladange.

Dari dua hal ini, SMP dan SMA di Camba menjadi catatan bahwa tidaklah karena soal lokasi sekolah yang menjadi penghalang.

Satu lagi, soal guru. Dimana pendidikan dasar kita ditopang oleh guru honorer. Merekapun hanya mendapatkan Rp. 700.000 perbulan. Sebuah angka yang relatif jikalau diukur dari besar atau kecil.

Hanya saja, dimana upah minimum provinsi jauh dari apa yang mereka terima. Belum lagi, soal guru kelas yang kemudian mengampuh mata pelajaran agama Islam.

Kendala-kendala ini kemudian melingkupi pendidikan dasar kita. Sementara pengangkatan pegawai dengan status $\mathrm{P} 3 \mathrm{~K}$, juga mengalami hambatan birokrasi.

Dengan keadaan seperti ini, langkah menuju pendidikan yang dapat dijadikan sebagai lokomotif perubahan, akan terkendala.

Belum lagi soal peran serta masyarakat untuk pengembangan pendidikan. Tidak adanya peluang untuk partisipasi masyarakat. Ketika itupun merupakan kesepakatan orang tua untuk urung rembug pada persoalan pendanaan akan terhambat pada regulasi dimana tidak dibolehkannya ada pembiayaan yang menjadi kategori "pungutan". 
Transformasi pendidikan kita, harus dicarikan jalan keluar. Dimana harus dibawa kepada solusi yang strategis sehingga tidak lagi membebani perubahan. Ketika ini menjadi sangkutan, maka itu kemudian justru akan berstatus pada sebuah kategori masalah.

Padahal, partisipasi masyarakat tidak pernah menjadi sebuah masalah. Mengirim putra/putri untuk berjauhan sekalipun, itu tetap dilakoni. Menjual tanah untuk keperluan fasilitas pendidikan publik juga diterima sebagai sebuah tuntutan bersama.

Maka, perlu ada keputusan strategis untuk mengurai masalah ini sehingga tidak lagi wujud di masa depan. Diperlukan kesamaan pandangan sehingga pendidikan Maros akan menjadi sarana dalam membawa masyarakat Maros memiliki daya saing global.

Jangankan berpartisipasi dalam persaingan global. Ketika guru dengan kemampuan berbeda, mengajar pada mata pelajaran tertentu. Ini bukan lagi sebuah proses belajar, tetapi semata-mata hanya datang ke sekolah yang belum tentu difasilitasi dengan guru yang menguasai kemampuan material. 